RAPID SPECTROPHOTOMETRIC DETERMINATION OF WATER-SOLUBLE INORGANIC PHOSPHORUS IN SOILS

\author{
Qiu Xing-chu, Zhang Yu-sheng, and Zhu Ying-quan* \\ Agricultural Science Research Institute of Ganzhou Prefecture, \\ Jiangxi, CHINA \\ * Present address : P. O. Box 82 , Chengdu, CHINA
}

\begin{abstract}
A more sensitive spectrophotometric method for phosphorus determination was developed. The effects due to acidity, time, reagent concentration, temperature and diverse ions are reported. The method is satisfactory for analysing water-soluble inorganic phosphorus in soils.
\end{abstract}

Numerous spectrophotometric methods are based on the formation of heteropoly acids, such as molybdo-, tungsto-, vanado-, and antimo-phosphoric acid, the heteropoly acids are usually determined with organic reagents ${ }^{1)-6)}$. They have high sensitivity, but possess some drawbacks. This paper reports that the molybdoantimophosphoric heteropoly acid reacts with crystal violet, in the presence of polyvinyl alcohol, to form a ion-associate complex in water solution at (0.34-0.54) $\mathrm{N}$ sulfuric acid, and phosphorus can thereby determined directly in aqueous solution. Optimum conditions for the color system have been studied, and water-soluble inorganic phosphorus in soils determined with satisfactory results.

\title{
EXPERIMENTAL
}

Apparatus

The absorbance measurements were carried out with a 72 type spectrophotometer (Shanghai Analytical Instruments Factory).

Reagents

Standard phosphorus solution : $50 \mu \mathrm{g} \mathrm{P} / \mathrm{ml}$.

Weigh out $109.9 \mathrm{mg}$ of potassium dihydrogen phosphate dried at $110^{\circ} \mathrm{C}$, dissolve in $300 \mathrm{ml}$ of water, and dilute to $500 \mathrm{ml}$ with water.

This solution contains $50 \mu \mathrm{g}$ phosphorus/ml and the working standard solution was prepared by dilution of this stock solution with water.

Mixed solution of concentrated sulfuric acid-ammonium molybdate-potassium antimonyl tartrate $(1.8 \mathrm{~N})$.

Water plus $50 \mathrm{ml}$ of concentrated sulfuric acid, $4 \mathrm{~g}$ of ammonium molybdate, and $45 \mathrm{ml}$ of $0.5 \%$ potassium antimonyl tartrate in a total volume of $1000 \mathrm{ml}$, and $\operatorname{mix}$ well.

Polyvinyl alcohol, $0.5 \%$ aqueous solution.

Crystal violet(Shanghai Chem. Ind. Mfg.) $0.05 \%$ aqueous solution. 
Water used was purified by distillation and ion exchange

Working procedure

Weight out $5.00 \mathrm{~g}$ of soil sample and put it into a 150-ml glass-stoppered conical flask. Add $50 \mathrm{ml}$ of water. Shake the flask for one hour. Then centrifuge, or filter the solution using a Büchner funnel. To an $10 \mathrm{ml}$ aliquot of the extract add $4 \mathrm{ml}$ of mixed solution of concentrated sulfuric acid-ammonium-molybdatepotassium antimonyl tartrate, $2 \mathrm{ml}$ of $0.5 \%$ polyvinyl alcohol and $4 \mathrm{ml}$ of $0.05 \%$ crystal violet solution, and mixed the solution after the addition of each reagent.

Allow it to stand at room temperature for $1 \mathrm{~h}$. Measure the absorbance at 550 $\mathrm{nm}$ in $1-\mathrm{cm}$ cell against a reagent blank prepared in the same manner but containing no phosphorus.

Calculate the content of phosphorus in the soil sample using the calibration graph obtained as follow.

Pipet phosphorus solution(containing 0.25-2.5 $\mu \mathrm{g}$ phosphorus) in a $50 \mathrm{ml}$ conical flask. Dilute to $10 \mathrm{ml}$ with water respectively, and proceed as described above. Plot the absorbance against phosphorus concentration.

\section{Absorption spectra}

\section{RESULTS AND DISCUSSION}

The absorption spectra of the ion-associate complex and the reagent blank were measured against water in the range 420-700 $\mathrm{nm}$ in 1-cm cells.

The absorption maximum of the ion-associate complex is at $550 \mathrm{~nm}$, whereas that of the reagent blank is at $627 \mathrm{~nm}(\mathrm{Fig}$. 1). Under this experimental condition, the molar absorptivity and Sandell's sensitivity of phosphorus are $1.33 \times 10^{5} \mathrm{l}_{\mathrm{mol}}^{-1}$

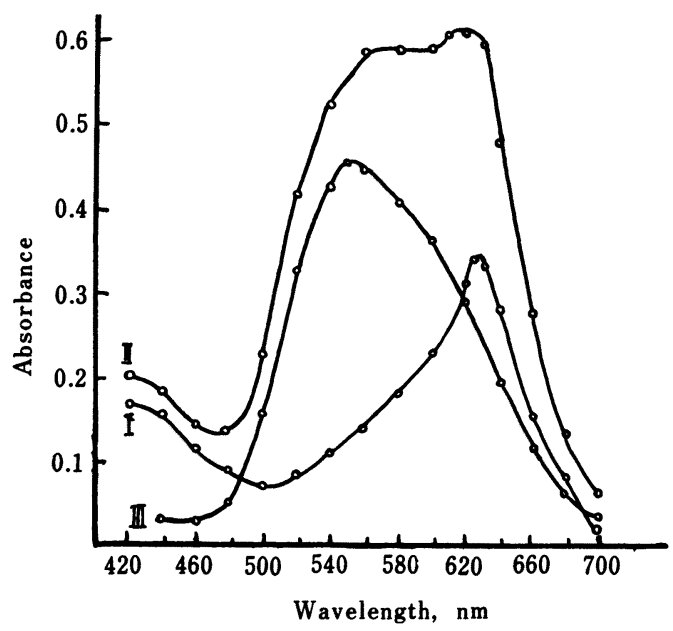

Fig. 1 Absorption curves

Curve I : Reagent blank(ref.:water); Curve II : Ion-associate complex(ref.: water); Curve III : Ion-associate complex (ref.:reagent blank); $\mathrm{P}$ taken : $2.00 \mu \mathrm{g}$; $0.36 \mathrm{~N} \mathrm{H}_{2} \mathrm{SO}_{4} ; 1.0-\mathrm{cm}$ cells $\mathrm{cm}^{-1}$ and $0.00023 \mu \mathrm{g} / \mathrm{cm}^{2}$ ( $A=0.001 \mathrm{unit}$, respectively.

Optimum acidity

The acidity from $0.3 \mathrm{~N}$ to $0.7 \mathrm{~N}$ was examined. When the solution was adjusted to various acidity values and treated as mentioned above, it was found taht the constant color develop-

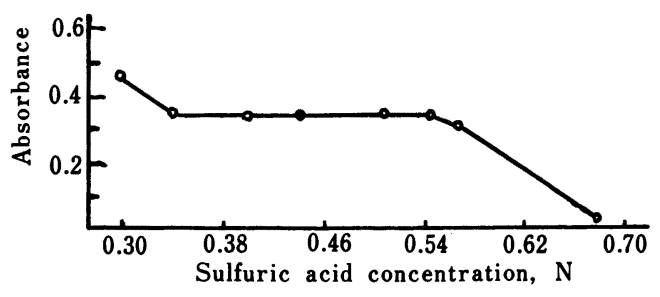

Fig. 2 Influence of acidity on the formation of ion-associate complex

$\mathrm{P}$ taken : $1.75 \mu \mathrm{g} ; 1.0-\mathrm{cm}$ cells 
ment was attained at acidity 0.34-0.54 $\mathrm{N}$ sulfuric acid(See Fig. 2). Therefore, $0.36 \mathrm{~N}$ sulfuric acid was chosen for the working procedure.

Optimum amounts of reagents added

Ammonium molybdate : The results shown in Fig. 3 depict that the absorbance increases with increasing amounts of the ammonium molybdate up to $2.0 \mathrm{ml}$ and then remains reasonably constant up to $7.0 \mathrm{ml}$. Hence, $4.0 \mathrm{ml}$ of the ammonium molybdate solution were found sufficient for the determination.

Potassium antimonyl tartrate : Constant absorbance readings were obtained

over the potassium antimonyl tartrate solution volume range 0.5-3.0 ml(See Fig. 4).

Polyvinyl alcohol : Constant absorbance readings were obtained over the polyvinyl alcohol solution volume range $1.0-3.5 \mathrm{ml}$ (See Fig. 5).

Crystal violet : The experimental results are presented in Fig. 6 . It appears that the constant absorbance readings were obtained over the crystal violet solution volume range $3-7 \mathrm{ml}$.

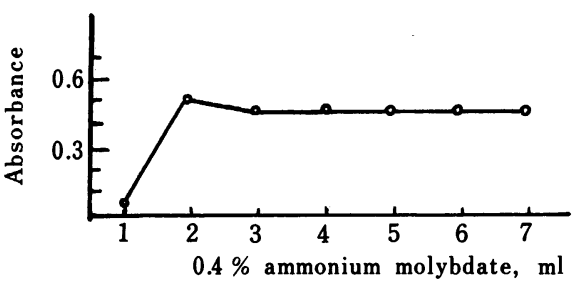

Fig. 3 Amount of ammonium molybdate needed

P taken : $2.25 \mu \mathrm{g} ; 1.0-\mathrm{cm}$ cells

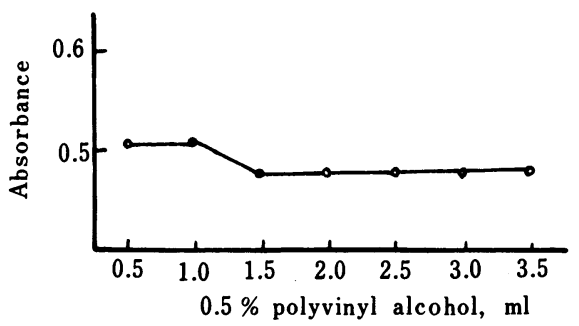

Fig. 5 Optimum amount of polyvinyl alcohol

P taken : $2.25 \mu \mathrm{g} ; 1.0-\mathrm{cm}$ cells

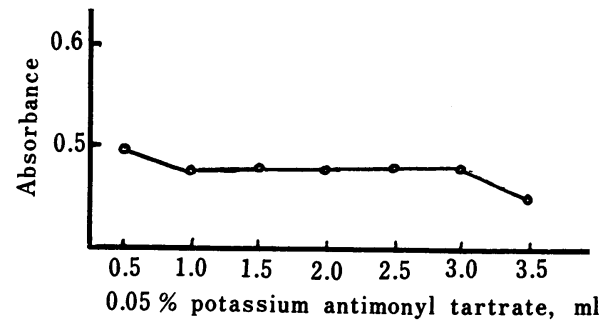

Fig. 4 Amount of potassium antimonyl tartrate needed

$\mathrm{P}$ taken : $2.25 \mu \mathrm{g} ; 1.0-\mathrm{cm}$ cells

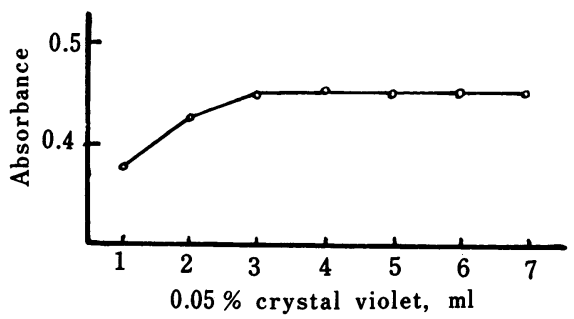

Fig. 6 Optimum amount of crystal violet solution

$\mathrm{P}$ taken : $2.00 \mu \mathrm{g} ; 1.0-\mathrm{cm}$ cells

Stability of the ion-associate complex

Around room temperature $\left(20-30^{\circ} \mathrm{C}\right)$, the color development requires about $40 \mathrm{~min}$, and is stable for at least $48 \mathrm{~h}$ (See Fig. 7).

Foreign ion study

Foreign ions were added to a $1 \mu \mathrm{g}$ phosphorus solution and the color was developed by the proposed procedure. Common metal ions(Fe, Mn, Ca, Mg, Al) and the following ions(when present in the amounts (in $\mu \mathrm{g}$ ) shown in brackets) did not inter- 


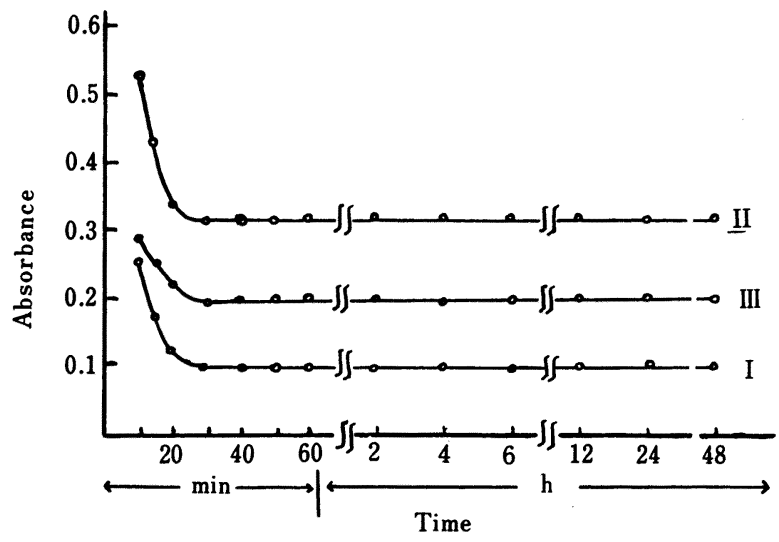

Fig. 7 Time for ion-associate complex formation

Curve I : Reagent blank ( against water as reference); Curve II : Ion-associate complex(against water as reference); Curve III : Ion-associate complex(against reagent blank as reference); $\mathrm{P}$ taken : $1.00 \mu \mathrm{g} ; 1.0-\mathrm{cm}$ cells

Table 1 Recovery of phosphorus

\begin{tabular}{|c|c|c|c|c|c|c|}
\hline \multirow[t]{2}{*}{ Soil } & \multirow{2}{*}{$\begin{array}{l}\text { Source of } \\
\text { parent } \\
\text { material }\end{array}$} & \multicolumn{3}{|c|}{$P(\mu g)$} & \multirow{2}{*}{$\begin{array}{c}\text { Error } \\
(\mu g)\end{array}$} & \multirow{2}{*}{$\begin{array}{c}\text { Recovery } \\
(q)\end{array}$} \\
\hline & & Original & Added & Found & & \\
\hline Red soil & $\begin{array}{l}\text { Quaternary } \\
\text { period red } \\
\text { clayey soil }\end{array}$ & 0.41 & $\begin{array}{l}0.25 \\
0.50 \\
0.75 \\
1.00\end{array}$ & $\begin{array}{l}0.61 \\
0.97 \\
1.23 \\
1.45\end{array}$ & $\begin{array}{l}-0.05 \\
+0.06 \\
+0.07 \\
+0.04\end{array}$ & $\begin{array}{r}93.8 \\
106.6 \\
106.0 \\
102.8\end{array}$ \\
\hline $\begin{array}{c}\text { Alluvial } \\
\text { soil }\end{array}$ & River drift & 1.15 & $\begin{array}{l}0.25 \\
0.50 \\
0.75 \\
1.00\end{array}$ & $\begin{array}{l}1.44 \\
1.64 \\
1.89 \\
2.17\end{array}$ & $\begin{array}{l}+0.04 \\
-0.01 \\
-0.01 \\
+0.02\end{array}$ & $\begin{array}{r}102.9 \\
99.4 \\
99.5 \\
100.9\end{array}$ \\
\hline $\begin{array}{l}\text { Purplish } \\
\text { soil }\end{array}$ & $\begin{array}{l}\text { Purple sand- } \\
\text { stone and shale } \\
\text { weathering } \\
\text { products }\end{array}$ & 0.90 & $\begin{array}{l}0.25 \\
0.50 \\
0.75 \\
1.00\end{array}$ & $\begin{array}{l}1.20 \\
1.47 \\
1.75 \\
1.98\end{array}$ & $\begin{array}{l}+0.05 \\
+0.07 \\
+0.10 \\
+0.08\end{array}$ & $\begin{array}{l}104.3 \\
105.0 \\
106.0 \\
104.2\end{array}$ \\
\hline
\end{tabular}

Table 2 Results for determination of inorganic phosphorus

\begin{tabular}{|c|c|c|c|c|}
\hline Soil & $\underset{(\mathrm{ppm})}{\operatorname{Results}}$ determined & Average & $\begin{array}{l}\text { Standard } \\
\text { deviation }\end{array}$ & $\begin{array}{l}\text { Coefficient of } \\
\text { variation }(8)\end{array}$ \\
\hline Red soil & $\begin{array}{llll}0.87, & 0.79, & 0.85, & 0.84, \\
0.85, & 0.78, & 0.83, & 0.81\end{array}$ & 0.828 & 0.0315 & 3.80 \\
\hline $\begin{array}{l}\text { Alluvial } \\
\text { soil }\end{array}$ & $\begin{array}{l}2.40,2.34,2.40,2.34, \\
2.42,2.35,2.40,2.43, \\
2.34\end{array}$ & 2.38 & 0.035 & 1.47 \\
\hline $\begin{array}{l}\text { Purplish } \\
\text { soil }\end{array}$ & $\begin{array}{l}1.18,1.18,1.18,1.17, \\
1.17,1.15,1.18 .1 .18, \\
1.15,1.17\end{array}$ & 1.17 & 0.012 & 1.03 \\
\hline
\end{tabular}

fere: $\mathrm{Si}(200), \mathrm{W}, \mathrm{Nb}$, and $\mathrm{Ti}($ each 40$), \mathrm{V}(20), \mathrm{As}(0.5)$.

Precision and accuracy

Results of experiments on the recovery of phosphorus are summarized in Table 1. From Table 1 it is seen that the recoveries of added standard solution 
are more than $94 \%$.

Table 2 lists the analytical results of phosphorus obtained by the method.

It is evident that the precision is good.

\section{REFERENCES}

1) L. Ducret, M. Drouillas : Anal. Chim. Acta, 21, 86 (1959).

2) F. P. Sudakov, V. I. Kletina, T. Ya. Danshova : Zh. Anal. Khim., 21, 1333 $(1966)$.

3) A. K. Babko, Yu. F. Shkaravskii, V. I. Kulik : Zh. Anal. Khim., 21, 196(1966).

4) Yu. F. Shkaravskii, K. A. Lynchak, V. B. Chernogorenko : Zavod. Lab., 36, 524 (1970).

5) A. K. Babko, Yu. F. Shkaravskii, E. M. Ivashkovich : Zh. Anal. Khim., 26, 854 (1971).

6) A. T. Pilipenko, Yu. F. Shkaravskii : Zh. Anal. Khim., 29, $716(1974)$.

7) Liu Shao-pu : Hauxue Tongbao(Chinese), $\underline{5}, 11(1981)$.

Keyword phrases

spectrophotometric determination of water soluble inorganic phosphorus; ion-associate complex of molybdo-, antimo-phosphoric heteropoly acid with crystal violet; in soils.

(Received Nov. 19, 1982) 